\title{
PENGEMBANGAN BAHAN AJAR SEJARAH TENTANG BIOGRAFI RADEN INTEN II UNTUK MENINGKATKAN KEMAMPUAN BERPIKIR KRITIS SISWA SMA NEGERI 2 SEKAMPUNG TAHUN 2015/ 2016
}

\author{
Febri Hartono, Rulianto \\ Universitas Mahasaraswati Denpasar \\ email:hartonofebri22@gmail.com
}

\begin{abstract}
ABSTRAK
Penelitian pengembangan ini bertujuan untuk menghasilkan sebuah media pembelajaran yang efektif untuk bisa memenuhi kebutuhan guru dan siswa dalam proses belajaran mengajar di sekolah. Media yang dihasilkan berupa bahan ajar sejarah tentang biografi Raden Inten II untuk meningkatkan kemampuan berpikir kritis dan penguatan karakter siswa SMA Negeri 2 Sekampung.Jenis penelitian pengembangan ini adalah pengembangan media dengan menggunakan model ADDIE (Analysis, Design, Development, Implementation, Evaluation). Populasi dalam penelitian ini adalah siswa kelas XI IPS SMA Negeri 2 Sekampung.Hasil penelitian menunjukan: (1) jenis media pembelajaran sejarah di SMA Negeri 2 Sekampung yang digunakan adalah jenis media lembar kerja siswa, buku pegangan dan buku paket, (2) bahan ajar sejarah di SMA tentang biografi Raden Inten II dilakukan melalului tahapan model ADDIE dan menghasilkan media bahan ajar dengan bentuk modul yang telah mengalami berkali-kali revisi dan telah tervalidasi oleh ahli media dan ahli materi serta selanjutnya berhasil di uji cobakan dalam pembelajaran di kelas XI IPS 3 SMA Negeri 2 Sekampung, (3) Uji efektivitas bahan ajar sejarah tentang biografi Raden Inten II dilakukan dengan membandingkan nilai post-test kelas eksperimen dan kelas kontrol dengan taraf signifikansi 5\% dan diperoleh hasil kemampuan berpikir kritisdengan $t_{\text {hit }} 3.700>t_{\text {tab }}$ 2.756 dan penguatan karakter dengan $\mathrm{t}_{\text {hit }} 4.168>\mathrm{t}_{\text {tab }}$ 1,697, dengan demikian maka H0 ditolak. Sehingga dapat disimpulkan bahwa media pembelajaran sejarah berupa bahan ajar sejarah tentang biografi Raden Inten II efektif untuk meningkatkan kemampuan berpikir kritis dan penguatan karakter siswa.
\end{abstract}

Kata Kunci: Bahan Ajar, Berpikir Kritis, Karakter

\begin{abstract}
This research development aims to produce an effective learning media which is more effective to fulfil the needs of teachers and students in the teaching and learning process in schools. Learning Media which was produced in the form of teaching materials in the subject history. The teaching material is about the biography of Raden Inten II to improve critical thinking skills and strengthening the character of the students in SMAN 2 Sekampung.This type of research is to develop the teaching media using a model ADDIE (Analysis, Design, Development, Implementation, Evaluation). Population in this research is class XI IPS SMAN 2 Sekampung. The sample of this study is implemented in three classes, they were class XI IPS 1 as an experimental class, a class XI IPS 2 as the control class, and class XI IPS 3 as the trials class.The results showed that: (1) the teaching media of history at SMAN 2 Sekampung used is student worksheets, handbook and textbooks; (2) teaching materials of history in high school about the biography of Raden Inten II made through model of ADDIE and generate materials teaching media to form a module that has undergone numerous revisions and has been validated by the experts of media and the expert of materials and subsequently successfully tested in the classroom of XI IPS 3 SMAN 2 Sekampung, (3) test of the effectiveness in teaching material history of biography Raden Inten II is done by comparing the value of post-test experimental class and control class with a significance level of $5 \%$ and result of students' ability to have critical think. It was proved from $t_{\text {hit }} 3,700>2,756 t_{\text {tab }}$ and the strengthening of character with $t_{\text {hit }} 4,168>1,697 t_{\text {tab. }}$. Therefore, $H 0$ is rejected. It can be concluded that the teaching media of history in the form of teaching materials about the history of biography Raden Inten II is effective to improve critical thinking skills and strengthening the character of the students SMAN 2 Sekampung.
\end{abstract}




\section{Keywords: $\quad$ Teaching Material, PENDAHULUAN}

Dengan semakin berkembangnya dunia pendidikan pada masa ini yang tadinya masih terpaku dengan pola pikir awam, pada saat ini pola pikir dalam dunia pendidikan menjadi lebih modern. Dengan hal demikian menuntut agar semua pendidik lebih melakukan inovasi dalam proses belajar mengajar sehingga siswa akan lebih senang dan lebih mudah untuk belajar. Tujuan dari pendidikan itu sendiri adalah menciptakan manusia yang berkualitas dan memiliki karakter yang luas sehingga mereka memiliki pandangan hidup yang jauh lebih baik dan lebih maju kedepan, karena pendidikan memotivasi seseorang untuk bisa menjadi lebih baik lagi. Hal tersebut senada dengan perbincangan diseputar pendidikan pada hakikatnya perbincangan manusia itu sendiri, artinya perbincangan diri sendiri sebagai yang berhak mendapat pendidikan karena dasar manusia dan muatan lainnya yang mempunyai nilai pragmatis dalam konteks sosioantropologis, seperti halnya sebuah pembangunan (Rosyadi, 2004: 17)

Winkel (dalam Sutikno, 2014: 12) pembelajaran merupakan seperangkat tindakan yang dirancang untuk mendukung proses belajar peserta didik dengan memperhitungkan kejadian-kejadian eksternal yang berperan terhadap rangkaian kejadian-kejadian internal yang berlangsung di dalam peserta didik. Dalam proses pembelajaran guru berperan sebagai fasilitator dan peserta didik mencari informasinya sendiri mengenani hal yang dipelajari, namun guru juga harus mampu mengarahkan siswa untuk dapat berpikir aktif dan inovatif. Jadi didalam belajar guru
Critical Thinking, Character bukanlah sumber segalanya, siswa dapat mencari informasi mengenai hal yang belum ia ketahui lewat berbagai sumber. Pelajaran sejarah selalu dianggap sebagai mata pelajaran yang kurang menarik serta membosankan, padahal pelajaran sejarah memiliki peranan penting dalam membentuk karakter peserta didik agar menjadi pribadi yang lebih baik. Dengan hal tersebut guru di tuntut untuk lebih inovatif dalam melakukan proses pembelajaran sejarah, sehingga siswa akan lebih termotivasi untuk belajar sejarah. Belajar yang berpusat pada guru juga harus dikurangi agar peserta didik mampu meningkatkan kemampuan berpikir kritis mereka.

Mata pelajaran sejarah sering dianggap kurang menarik oleh peserta didik, padahal mata pelajaran sejarah memiliki posisi yang strategis dalam dunia pendidikan karakter bangsa. Di dalam materi pokok pembelajaran yang diberikan di SMA kelas XI adalah perlawanan rakyat Indonesia terhadap kekuasaan asing, yang di dalamnya terdapat banyak hal yang dapat peserta didik pelajari. Peserta didik banyak yang menganggap bahwa materi tersebut hanya biasa-biasa saja, mereka hanya akan mengerti bahwa pangeran diponegoro adalah salah satu pahlawan nasional indonesi tanpa mengetahui bagaimana kronologis perlawanan yang dilakukan, bagaimana sosok diponegoro, dan peserta didik juga tidak mengetahui apakan ada sosok pahlawan nasional yang berasal dari daerah mereka yang ikut berjuang melawan penjajah. Sehingga dari hal tersebut, salah satu model pebelajaran yang diangga sesuai dengan kondisi sekolah peserta didik 
adalah model pembelajaran dengan menggunakan bahan ajar.

Proses pembelajaran seharusnya diselenggarakan secara interaktif, inspiratif dalam suasana yangmenyenangkan, menggairahkan, menantang, memotivasi peserta didik untuk berpartisipasi aktif, serta memberikan ruang yang cukup bagi prakarsa, kreativitas, dan perkembangan fisik serta psikolog peserta didik. Lindgren (dalam Sutikno, 2012: 13) fokus sistem pendidikan mencakup aspek, yaitu (1) peserta didik merupakan faktor yang paling penting sebab tanpa pesrta didik tidak akan ada proses belajar, (2) proses belajar adalah apa saja yang dihayai peserta didik apabila mereka belajar, bukan apa yang harus dilakukan untuk membelajarkan materi-materi pelajaran melainkan apa yang akan dilakukan peserta didik untuk mempelajarinya, dan (3) situasi belajar adalah lingkungan belajar tempat terjadinya proses belajar dan semua faktor yang mempengaruhi peserta didik atau proses belajar seperti guru, kelas, dan interaksi di dalamnya.

\section{Berdasarkan hasil pengamatan} observasi serta wawancara dengan guru mata pelajaran sejarah di SMA Negeri 2 Sekampung, peneliti menemukan bahwa selama ini metode pembelajaran yang masih sering digunakan oleh guru adalah metode ceramah, yaitu dimana guru memberikan informasi pengetahuan secara verbal kepada peserta didik, meskipun bisa dengan menerapkan metode lainnya. Sedangkan pembelajaran menggunakan slide power point sangat jarang digunakan oleh guru mata pelajaran sejarah, sehingga siswa selalu beranggapan bahwa mata pelajaran sejarah membosankan, monoton dan tidak menarik. Dengan demikian peserta didik cenderung kurang bersemanagat dalam proses pembelajaran dan menerima pembelajaran sejarah yang dilakukan. Apalagi ketika mata pelajaran sejajah yang dilaksanakan pada jam siang hari, siswa seperti kurang mendengarkan dan bermalas-malasan. Dalam proses tes yang dilakukan oleh guru, peserta didik cenderung kurang memikirkan pertanyaan yang dikerjakan, mereka hanya membaca sekilas soal tersebut tanpa memikirkan dengan mendalam soal tersebut. Hasil pengamatan juga mendapatkan hasil karakter peserta didik yang masih sangat rendah dilihat dari masih banyaknya peserta didik yang terlambat, membolos saat jam pelajaran, serta kurang sopan terhadap guru ketika proses pembelajaran sedang berlangsung.

Sehingga dengan hal tersebut, peneliti bermaksud ingin menerapkan media pembelajaran berupa bahan ajar dengan menggunakan biografi sosok pahlawan nasional yang berasal dari daerah peserta didik agar mata pelajaran sejarah lebih menarik dan disukai oleh peserta didik. Dengan adanya media pembelajaran berupa bahan ajar sejarah di SMA pada nantinya selain peserta didik memperoleh ilmu pengetahuan, mereka juga mendaparkan pengetahuan baru mengenai sosok pahlawan nasional dari daerah mereka. Dan nantinya diharapkan peserta didik dapat mentauladani sikap pahlawan nasional sebagai contoh dan bisa menjadikan mata pelajaran sejarah menjadi mata pelajaran yang disukai serta menjadikan peserta didik lebih mampu meningkatkan kemampuan berpikir kritis dan karakter mereka. 
Penelitian ini bertujuan untuk menghasilkan sebuah media pembelajaran berupa bahan ajar sejarah yang efektif untuk bisa memenuhi kebutuhan guru serta peserta didik dalam proses interaksi belajar mengajar di sekolah. Media pembelajaran sejarah yang dihasilkan adalah berupa bahan ajar sejarah tentang biografi Raden Inten II untuk meningkatkan kemampuan berpikir kritis dan penguatan karakter siswa.Dalam proses pembelajaran guru memiliki tugas untuk mencerdaskan peserta didik, mendorong, membimbing dan memberikan fasilitas belajar bagi peserta didik agar dapat mencapai tujuan belajara. Guru memiliki tanggung jawab melihat segala sesuatu yang terjadi didalam kelas untuk membantu proses pengembangan peserta didik. Mata pelajaran sejarah memiliki arti yang strategis dalam pembentukan watak dan peradaban bangsa yang bermartabat serta dalam pembentukan manusia Indonesia yang memiliki rasa kebangsaan dan cinta tanah air (Aman, 2011: 57).

Agung \& Wahyuni (2013: 55-57) sejarah adalah mata pelajaran yang menanmkan pengetahuan, sikap, dan nilainilai mengenai proses perubahan dan perkembangan masyarakat Indonesia dan dunia dimasa lampau hingga masa kini. Kemudia pengajarah sejarah disekolah bertujuan agar peserta didik memperoleh kemampuan berpikir historis dan pemahaman sejarah. Dengan pelajaran sejarah diharapkan peserta didik akan bisa berpikir secara kritis terhadap sebuah peristiwa atau kejadian yang pernah terjadi, dan siswa akan dapat menangkap makna serta arti yang terkandung dalam peristiwa tersebut. Seifert (2010: 197) berpikir kritis dapat didefinisikan secara formal maupun informal, secara formal dijelaskan oleh Facione, Facione, dan Sanchez mengacu kepada proses pembuatan keputusan beralasan berdasarkan pertimbangan bukti yang ada, aspek kontekstual dari sebuah situasi, dan konsep. Kemudian definisi secara informal adalah memutuskan apa yang harus dilakukan dan kapan, dimana, mengapa, dan bagaimana melakukannya.

Selanjutnya dengan kemampuan berpikir kritis peserta didik telah meningkat dengan baik, tentunya itu semua akan menjadikan peserta didik memili karakter yang lebih baik juga. (Daryanto dan Darmiatun, 2013: 9) watak atau karakter merupakan perpaduan dari segala tabiat manusia yang bersifat tetap sehingga menjadi tanda khusus untuk membedakan orang yang satu dengan yang lainnya. Sedangkan (Aqib, 2012: 26) karakter adalah ciri-ciri yang unik dan terpatri di dalam diri seseorang yang terlihat dalam sikap, prilaku dan tindakan yang terjawantahkan secara konsisten dalam merespon berbagai situasi.

Dalam mengembangkan media pembelajaran berupa bahan ajar sejarah, model desain yang digunakan dalam pengembangannya adalah model ADDIE.Bahan ajar harus dapat digunakan sebagai pengganti dari fungsi pendidik, (Prastyo, 2011: 104) modul atau bahan ajar diartikan sebagi sebuah buku yang ditulis dengan jujur agar siswa dapat belajara secara secara mandiri tanpa atau dengan bimbingan guru. Sedangkan (Daryanto, 2013: 9) modul atau bahan ajar merupakan salah satu bentuk bahan ajar yang dikemas secara utuh dan sistematis, didalamnya memuat seperangkap 
pengalaman belajar terencana dan di desain untuk membantu peserta didik menguasai tujuan belajar yang spesifik.

Berdasarkan hasil kajian teori dan pengamatan yang dilakukan dilapangan, diajukan model hipotetik media pembelajaran berupa bahan ajar untuk meningkatkan kemampuan berpikir kritis dan penguatan karakter siswa. Model hipotetik ini mengadopsi dari model ADDIE (Molenda: 2008: 107-109) yang dimana model ADDIE menggunakan lima tahapan dalam pengembangnnya, yaitu:

1. Analysis (Analisis)

2. Design (Desain/ Rancangan)

3. Development (Pengembangan)

4. Implementation (Implementasi)

5. Evaluation (Evaluasi)

\section{METODE PENELITIAN}

Lokasi penelitia ini dilakukan di SMA Negeri 2 Sekampung Kabupaten Lampung Timur Lampung, dan juga makam pahlawan nasional Raden Inten II yang berada di kalianda Lampung Selatan. Pemilihan lokasi penelitian berdasarkan alasan serta pertimbangan sebagai berikut: alasan utama memilih SMA Negeri 2 Sekampung merupakan salah satu SMA yang mendukung pembelajaran dengan menggunakan media bahan ajar, serta siswa yang memiliki beragam pengetahuan mengenai sejarah. Selain hal tersebut juga dikarenakan Raden Inten II merupakan salah satu pahlawan nasional yang berasal dari Lampung, hal itu sesuai dengan lokasi SMA yang berada di Lampung.Dengan hal tersebut peneliti sangat tertarik melakukan penelitian di SMA tersebut. Selanjutnya tempat yang akan dijakian pengambilan foto adalah makan
Raden Inten II yang terletak di Kalianda Lampung Selatan, selain itu juga guna mendapat informasi yang lebih mendalam mengenai biografi Raden Inten II.

Penelitian pengembangan atau juga disebut Research and Development, memberikan sebuah gambaran bahwa penelitian yang dilakukan menekankan pada sebuah proses untuk menghasilkan sebuah produk tertentu yang pada nantinya akan digunakan dalam dunia pendidikan serta dapat juga digunakan untuk menambah pengetahuan baru. Dalam penelitian ini, pengembangn yang dilakukan adalah pengembanagan media pembelajaran berupa bahan ajar sejarah. Sugiyono (2013: 297) metode penelitian dan pengembangan atau dalam Bahasa Inggris Research and Development adalah sebuah metode penelitian yang digunakan untuk menghasilkan sebuah produk tertentu, dan menguji keefektifan produk tersebut.

Pendekatan penelitian dan pengembangan dianggap sesuai karena memiliki tujuan menghasilkan produk media pembelajaran berupa bahan ajar yang efektif dan efisien sesuai dengan kondisi serta keadaan yang ada sebenarnya di daerah peserta didik dan lingkungan mereka. Dalam penyusunan penelitian pengembangan terdapat beberapa langkah yaitu: 1) potensi dan masalah, 2) pengumpulan data, 3) desain produk, 4) validasi desain,5) uji coba pemakaian, 6) revisi produk, 7) uji coba produk, 8) revisi desai, 9) revisi produk, dan 10) produksi masal (Sugiyono, 2013 : 298). Dari langkah-langkah penelitian pengembangn tersebut, demi kepentingan penyusunan tesis dilakukan penyerderhanaan dalam langkah-langkah pengembangannya 
yaitu meliputi, penelitian pendahuluan dan perencanaan, pengembangan media bahan ajar, serta penerapan media dan evaluasi media yang telah digunakan.

Dalam penelitian ini ada beberapa instrument yang digunakan, diantaranya adalah: lembar observasi, kuesioner (lembar validasi), serta pedoman wawancar. Lembar observasi dan wawancara digunakan untuk informasi-informasi yang diperlukan dari lapangan serta sebagai penelitian pendahuluan. Kuesioner (lembar validasi) digunakan untuk layak atau tidak media yang dikembangkan untuk digunakan. Data-data yang dikumpulkan dalam penelitian ini adalah data awal penelitian pendahuluan, data penilaian dari ahli baik ahli media maupun ahli materi pembelajaran, data hasil wawancara dengan guru dan siswa, serta data hasil uji coba yang dilakukan. Sehingga teknik pengumpulan data yang dilakukan adalah observasi, validasi, wawancara, serta uji coba.

\section{HASIL DAN PEMBAHASAN}

Penelitian yang dilakukan diawali dengan melakukan studi pendahuluan, dimana studi pendahuluan ini dilakukan berdasarkan sumber hasil observasi lapangan pada sekolah SMA Negeri 2 Sekampung. Aspek yang dilihat dalam studi pendahuluan ini diantaranya adalah profil sekolah, sarana prasarana, guru mata pelajaran sejarah, perangkat pembelajaran, siswa SMA Negeri 2 Sekampung, serta hasil belajar siswa.

Kemudian wawancara dilakukan terhadap guru mata pelajaran sejarah dan juga beberapa siswa kelas XI. Dari hasil wawancara diperoleh hsil bahwa penggunaan media pembelajaran dalam proses belajar mengajar yang dilakukan masih sangat minim, guru masih terpaku dengan metode cerama. Dalam hal ini guru masih belum mengembangkan sebuah media pembelajaran dikarenakan oleh beberapa hal yaitu waktu yang digunakan untuk mengembangkan sebuah medi, jarak yang jauh, serta biaya yang tidak ada untuk mengembangkan sebuah media pembelajaran. Berikut ini adalah salahsatu bentuk dari hasil pengembangan modul tentang biografi Raden Inten II:

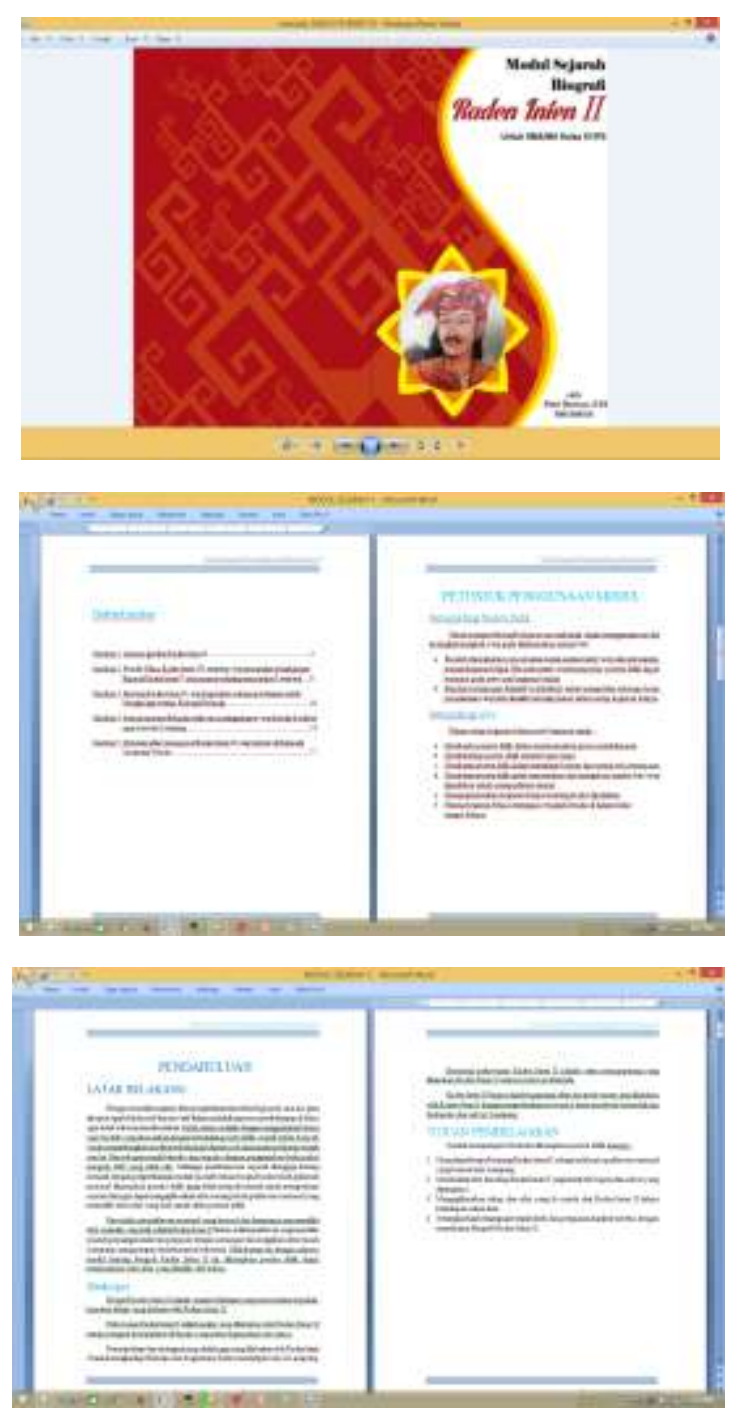




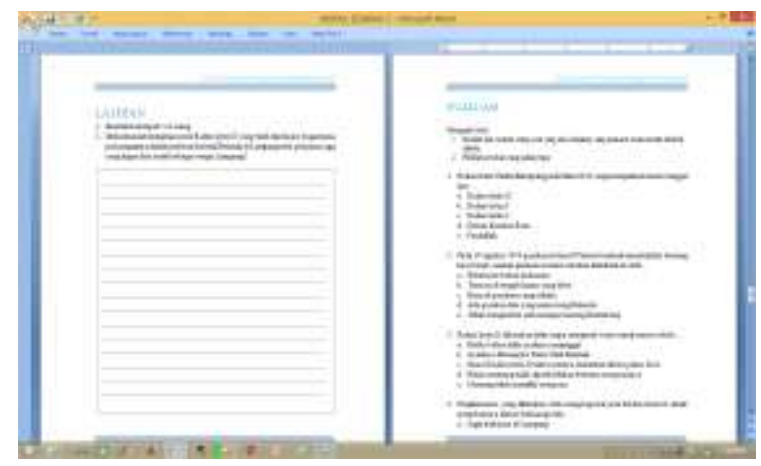

Gambar 1. Bentuk Modul Tentang Biografi Raden Inten II

Bentuk modul yang telah dikembangkan, memiliki makna dari cover modul dengan warna merah memiliki makna akan keberanian sosok Raden Inten II yang masih muda serta di padukan dengan warna putih yang memiliki makna memperjuangkan bangsa Indonesia. Dalam modul yang dikemabangkan juga dilengkapi dengan petunjuk penggunaan modul bagi guru maupun bagi peserta didik. Modul tenang biografi Raden Inten II yang dikembangkan memiliki isi mengenai bagaimana sosok Raden Inten II mulai dari kehidupan beliau, perjuangan bilau, bahkan hingga beliau wafat tercantum di dalam modul ini. Selain hal tersebut modul ini juga dilengkapi dengan soal kemampuan untuk mengukur seberapa jauh pengetahuan siswa setelah mempelajari modul tentang biografi Raden Inten II.

Siswa menyambut dengan sangat antusias media pembelajaran berupa bahan ajar yang dikembangkan, karena siswa mendapatlan pemahaman baru dan juga mendapatkan media yang menarik untuk menambah pengetahuan mereka. Untuk dapat meningkatkan minat belajar dan juga kemampuan berpikir siswa, guru harus banyak memanfaatkan media pembelajaran agar siswa lebi kreatif dan juga antusias dalam belajar. Berdasarkan hasil observasi serta wawan cara yang dilakukan terhadap guru dan juga siswa, diperoleh hasil sebagai berikut:

1. Guru dalam melakukan proses belajar mengajar masih terpaku dengan menggunakan metode ceramah, dan juga masih minim dalam penggunaan media pembelajaran.

2. Materi sejarah yang diberikan masih monoton dengan apa yang ada di dalam buku teks yang digunakan.

3. Ada keinginan guru untuk mengembangkan sebiah media pembelajaran yang inovatif, kreatif serta efisien untuk menarik minat belajar siswa namun terhalang berbagai kendala.

4. Masih rendahnya kemampuan berpikir kritis siswa serta karakter siswa yang masih kurang baik.

5. Siswa menginginkan sebuah media pembelajaran yang inovatif yang tidak hanya belajar menggunakan buku teks dan juga metode ceramah saja.

6. Guru dan siswa menginginkan sebuah media pembelajaran yang memudahkan siswa dan juga guru dalam melakukan proses belajae mengajar.

Setelah modul diterapkan dalam pembelajaran kemudian di ukur hasilnya dengan menggunkan program SPSS apakah ada perbedaan peningkatan kemampuan berpikir kritis dan penguatan karakter siswa yang menggunakan media berupa bahan ajar sejarah tentang biografi Raden Inten II dengan kelas yang hanya menggunakan buku teks saja. Berikut ini hasil uji yang dilakukan:

Hasil uji kemampuan berpikir kritis terhadap siswa yang menggunakan media 
berupa bahan ajar tentang biografi Raden menggunakan buku teks saja. Inten II dengan kelas yang hanya

Tabel 1. Hasil Efektivitas Kemampuan Berpikir Kritis Siswa

T-Test

Group Statistics

\begin{tabular}{lcccrrr}
\hline Kemampuan Berpikir Kritis & $\mathrm{n}$ & $\mathrm{N}$ & Mean & $\begin{array}{c}\text { Std. } \\
\text { Devistion }\end{array}$ & Std. Error Mean \\
\hline Post Test Kemampuan & 1 & 30 & 79.73 & 3.921 & .716 \\
Berpikir Kritis Kelas & 2 & 30 & 76.27 & 3.311 & .604 \\
Eksperimen dan Kontrol & & & & & \\
\hline
\end{tabular}

Independent Samples Test

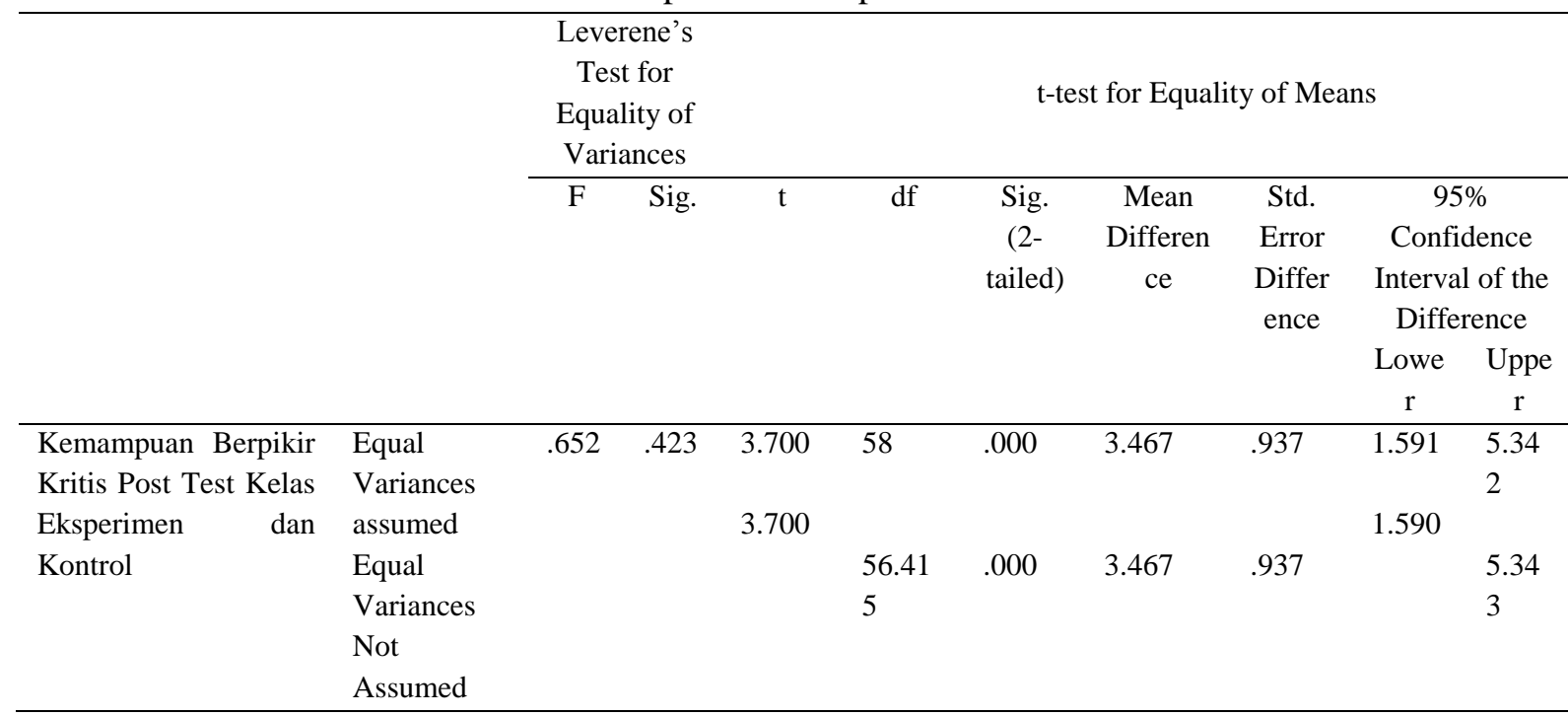

Berdasarkan hasil uji kemampuan Raden Inten II dibandingkan dengan kelas berpikir kritis yang dilakukan diperoleh hasil nilai sig 0,000 kurang dari 0,05 , sehingga dapat diambil kesimpulah bahwa $\mathrm{HO}$ ditolah karena nilai sig $<0,05$ dan dapat diambil pengertian bahwa adanya perbedaan kemampuan berpikir kritis antara kelas yang menggunkan bahan ajar tentang biografi yang hanya menggunkan buku teks saja.

Tabel 1. Hasil Efektivitas Kemampuan Berpikir Kritis Siswa

T-Test 
Group Statistics

\begin{tabular}{lrrrrrr}
\hline Prestasi & N & N & Mean & \multicolumn{1}{c}{ Std. Devistion } & Std. Error Mean \\
\hline Post Test Angket Kelas & 1 & & 30 & 135.53 & 2.515 & .459 \\
Eksperimen dan Kontrol & 2 & & 30 & 133.00 & 2.181 & .398 \\
\hline
\end{tabular}

Independent Samples Test

\begin{tabular}{|c|c|c|c|c|c|c|c|c|c|c|}
\hline & & \multicolumn{2}{|c|}{$\begin{array}{c}\text { Leverene's Test } \\
\text { for Equality of } \\
\text { Variances }\end{array}$} & & \multicolumn{6}{|c|}{ t-test for Equality of Means } \\
\hline & & \multirow[t]{2}{*}{$\mathrm{F}$} & \multirow[t]{2}{*}{ Sig. } & \multirow[t]{2}{*}{$\mathrm{t}$} & \multirow[t]{2}{*}{$\mathrm{df}$} & \multirow[t]{2}{*}{$\begin{array}{l}\text { Sig. (2- } \\
\text { tailed) }\end{array}$} & \multirow[t]{2}{*}{$\begin{array}{c}\text { Mean } \\
\text { Differe } \\
\text { nce }\end{array}$} & \multirow{2}{*}{$\begin{array}{c}\text { Std. } \\
\text { Error } \\
\text { Diffe } \\
\text { rence }\end{array}$} & \multicolumn{2}{|c|}{$\begin{array}{l}\text { 95\% Confidence } \\
\text { Interval of the } \\
\text { Difference }\end{array}$} \\
\hline & & & & & & & & & Lower & Upper \\
\hline $\begin{array}{l}\text { Angket Post } \\
\text { Test Kelas }\end{array}$ & Equal Variances & .0 .32 & .858 & 4.168 & 58 & .000 & 2.533 & .608 & 1.317 & 3.750 \\
\hline $\begin{array}{l}\text { Eksperimen } \\
\text { dan Kontrol }\end{array}$ & $\begin{array}{l}\text { Assumed } \\
\text { Equal Variances } \\
\text { Not Assumed }\end{array}$ & & & 4.168 & 56.863 & .000 & 2.533 & .608 & 1.316 & 3.751 \\
\hline
\end{tabular}

Berdasarkan hasil uji karakter yang dilakukan diperoleh hasil nilai sig 0,000 kurang dari 0,05 , sehingga dapat diambil kesimpulah bahwa $\mathrm{H} 0$ ditolah karena nilai sig $<0,05$ atau adanya peningkatan karakter siswa yang menggunakan media bahan ajar di bandingkan dengan yang tidak menggunakan Pengembangan Media Pembelajaran Berupa Bahan Ajar Sejarah di SMA Negeri 2 Sekampung

Pengembangan media pembelajaran berupa bahan ajar sejarah yang dilakukan di SMA Negeri 2 Sekampung dilakukan dengan landasan pengembangan sebuah bahan ajar. Bahan ajar yang akan diberikan kepada peserta didik perlu disesuaikan dengan tingkat perkembangan penserta didik.

Menurut Kodir (2011: 221) mengungkapkan prinsip bahan ajar adalah sebagai berikut: 1) disusun dari materi yang mudah untuk memahami yang lebih sulit, dan dari yang konkrit untuk memahami yang semikonkret dan abstrak, 2) menekankan pengulangan untuk memperkuat pemahaman, 3) umpan balik yang positif akan memberikan penguatan terhadap peserta didik, 4) motivasi media bahan ajar yang dikembangkan dan dapat diambil pengertian bahwa adanya perbedaan antara kelas yang menggunkan bahan ajar tentang biografi Raden Inten II dibandingkan dengan kelas yang hanya menggunkan buku teks saja.

adalah salah satu upaya yang dapat menentukan keberhasilan belajar, dan 5) latihan dan tugas untuk menguji sejauhmana pengetahuan peserta didik. Sedangkan pengembangan sebuan media pembelajaran menurut Daryanto (2013: 12), landasan teoritik pengembangan media pembelajaran meliputi: (1) menurut landasan filosofi, proses pembelajaran yang menggunaan media pembelajaran yang dilakukan tetap harus menggunakan pendekatan humanis; (2) landasan psikologi, dalam memilih media pembelajaran di samping memperlihatkan kompleksitas dan keunikan proses belajar, memahami makna persepsi serta faktor-faktor yang berpengaruh terhadap penjelasan persepsi seharusnya diupayakan secara optimal agar proses pembelajaran dapat berlangsung secara efektif; (3) landasan 
teknologis, pemecahan masalah dilakukan dalam bentuk: kesatuan komponen-komponen sistem pembelajaran yang disusun dalam fungsi desain atau seleksi, dan dalam memanfaatkan serta mengkombinasikan sehingga menjadi sistem pembelajaran yang lengkap; (4) landasan empirik, pemilihan media seharusnya mempertimbangkan kesesuaian antara karakteristik pebelajar, karakteristik materi pelajaran, dan karakteristik media itu sendiri.

\section{SIMPULAN}

Berdasarkan hasil penelitian pengembangan yang telah dilakukan mengenai pengembangan bahan ajar sejarah tentang biografi Raden Inten II untuk meningkatkan kemampuan berpikir kritis dan penguatan karakter siswa SMA Negeri 2 Sekampung, maka dapat diambil kesimpulan sebagai berikut:

1. Penggunaan media pembelajaran di SMA Negeri 2 Sekampung yang tadinya hanya menggunakan media berupa buku teks saja, oleh peserta didik hal itu terasa sangat membosankan. Kemudian dikembangkan sebuah media pembelajaran berupa bahan ajar sejara yang kemudian diterapkan di kelas XI IPS 1 SMA Negeri 2 Sekampung dan diperoleh hasil bahwa terdapat peningkatan kemampuan berpikir kritis siswa, yang dimana hal tersebut dilihat dari hasil uji $\mathrm{t}$ yang dilakukan. Hasil yang diperoleh adalah $\mathrm{t}_{\text {hit }} 3.700$ sedangkan untuk $\mathrm{t}_{\mathrm{tab}} \quad 2.756$ (taraf signifikansi 5\%), sehingga dapat disimpulkan bahwa H0 ditolak karena adanya peningkatan kemampuan berpikir kritis siswa yang menggunakan media pembelajaran berupa bahan ajar sejarah tentang biografi Raden Inten II dibandingkan dengan kelas yang hanya menggunakan media buku teks saja.

2. Kemudia media yang telah dikembangkan telah dilakuakan penilaian yang dilakukan oleh ahli media serta ahli materi pembelajaran, yang dimana ahli media berjumlah 2 orang dan juga ahli materi berjumlah 2. Hasil validasi yang dilakukan oleh ahli media mendapatkan nilai 4,3 dan 4,6 sehingga jikan di ukur dengan skala 5 maka media yang dikembangkan dinyatakan baik oleh kedua ahli media tersebut. Kemudian validasi yang dilakukan oleh ahli materi mendapatkan nilai sebesar 4,3 dan 4,7, apabila di ukur dengan menggunakan skala 5 maka media yang dikembangkan juga dinyatakan baik oleh ahli materi pembelajaran.

3. Serta media pembelajaran berupa bahan ajar sejarah tentang biografi Raden Inten II dapat menguatkan karakter siswa, hal tersebut dilihat dari hasil perhitungan yang dilakukan dengan hasil yang diperoleh $\mathrm{t}_{\text {hit }}$ 4,168 sedangkan untuk $\mathrm{t}_{\text {tab }}$ 1,697. Sehingga dari hal tersebut dapat diambil kesimpulan bahwa adanya penguatan karakter siswa yang menggunakan media berupa bahan ajar sejarah tentang biografi Raden Inten II di banding dengan siswa yang hanya menggunakan media berupa buku teks saja.

\section{DAFTAR PUSTAKA}

Agung S. L. Wahyuni. S. 2013.Perencanaan Pembelajaran

Sejarah.Yogyakarta:Ombak 
Aman. 2011. Model Evaluasi PembelajaranSejarah, Yogyakarta: Ombak

Aqib, Z. 2012. Pendidikan Karakter di Sekolah, Bandung: rama Widya

Daryanto. 2013. Menyusun Modul. Yogjakarta: Gava Media

Daryanto dan Darmiatu, Suryatri. 2013. Implementasi Pendidikan Karakter diSekolah, Yogyakarta : Gava Media

Kowiyuh, K. 2012. Kemampuan Berpikir kritis Jurnal Pendidikan Dasar,Google Cendikia

Seifert, Patricia C, 2010. Thinking Critically, AORN Journal Vol 91 No 2

Sutikno, S. 2014. Metode \& Modelmodel Pembelajaran. Perpustakaan Nasional: Holistica Lombok

Sugiyono. 2013. Metode PenelitianKuantitatif, Kualitatif Dan $R \& D$,

Bandung:Alfabeta 